\title{
State financial security: Comprehensive analysis of its impact factors
}

\author{
Inna Shkolnyk \\ Department of Finance, Banking and Insurance, \\ Sumy State University, \\ Ukraine \\ innasbkolnik@ukr.net
}

\section{Serhiy Kozmenko}

University of Social Science,

Lodz, Poland

kormenko.uabs@gmail.com

\section{Jiri Polach}

College of Entrepreneurship and Law,

Prague, Czech Republic

polach@,vspp.cz.

ORCID 0000-0002-2224-0414

Elżbieta Wolanin

Department of Quantitative Methods, Faculty of Management

Rzeszow University of Technology,

Rzeszów, Poland

e.wolanin@pr.edu.pl

Abstract. Ensuring the financial security of a country is one of the main Received: tasks in formulating strategic objectives for the development of the financial system. Given that each country has its own characteristics in terms of the financial architecture, which manifests itself in its model, in the state of public finances and their importance for the economic development of a country, etc., the assessment of the financial security status will have its differences not only in the list of indicators, but also in the structural relations among them. October, 2019 1st Revision: March, 2020 Accepted: May, 2020 Therefore, this study assessed the level of financial security, carried out its structural analysis, and identified the factors influencing it, using the case of Poland and Ukraine. Based on data for 2007-2018, the countries' financial security is analyzed by four indicator groups that characterize the development level of financial institutions, 
monetary market, stock market and public finance. Using Harrington's Desirability Function, an integrated financial security indicator was created for each country. Both countries showed a positive trend to increase the level of financial security, while the value of the financial security indicator corresponds to the desired, satisfactory, level. At the end of the analyzed period, Poland showed a high level of financial security. For factor analysis, the factors were selected that characterized Freedom from corruption, Property rights, Fiscal freedom, Business freedom, Labor freedom, Trade freedom, and Investment freedom. As a result, it was found that, Freedom from corruption and Business freedom had the greatest impact on the level of financial security in Poland, while Business freedom and Trade freedom were the most influential on the financial security of Ukraine.

Keywords: system, financial institute, public finance, money, stock market, stability.

JEL Classification: E51, E6

\section{INTRODUCTION}

The level of financial security of a country is an important characteristic that reflects the state of its financial system. This level depends on many factors, which can vary significantly when considering countries with different levels of economic development. The financial system of each country has its own characteristics; they are defined by formulated channels of financial resources flows of all economic agents, the predominance of various financial intermediaries, which is manifested in the concentration of financial flows through stock exchanges, or vice versa banks act as the main financial intermediaries. In addition, public finances play an important role, and their impact on economic development in each country can vary from high enough to low enough. Understanding the state and development trends of the structural elements that shape the indicator of the state's financial security, and assessing the main factors influencing it, allows us to determine and timely adjust the strategic priorities for the development of the country's financial system. Therefore, it is necessary to conduct an in-depth structural analysis and identify the major factors of a country's financial security. The purpose of the article is to determine the level of financial security of the countries, analyze their structure and evaluate factors of influence using financial systems of Ukraine and Poland as an example.

\section{LITERATURE REVIEW}

Financial security of a country is the focus of attention of scientists from different countries at different development levels of financial systems. Advanced economies conduct more research related to ensuring their financial stability, due to their role in the global financial architecture and their impact on the financial systems of less economically developed countries. It is obvious that the financial markets of advanced countries and their stability significantly influence the development of the financial markets of states with emerging and border markets (Blahun I. S. \& Blahun, I. I., 2020). The World Bank's experts (DemirgüçKunt et al., 2012, 2013), based on a study of strengths and weaknesses of the emerging financial architecture 
in different countries, developed a 4x2 financial stability matrix and proposed four groups of indicators depth, assets, efficiency and stability - for financial institutions and financial markets. The set of indicators is wide, therefore it is not possible to use them as a standard for all countries, since the structure and level of development of financial systems differ, and currently there is no set of statistical information on individual parameters in individual countries. Therefore, it is necessary to determine their list individually within countries or regions.

It is worth noting that ensuring a high level of a country's financial stability significantly affects its socio-economic development (Shkolnyk et al., 2019; Belas et al., 2018), and therefore research in this area is extremely important. It is should be also noted that many publications with results of financial stability studies in different countries and regions relate to the relationship between financial stability and risks in monetary policy and the functioning of banking systems (Gavurova et al., 2017b; Valaskova et al., 2018) . A well-developed banking industry is more likely to help maintain the stability of a financial market and avoid banking crises (Ruinan, 2019). The study by Belas et al. (2019) aimed to find out which banking sector specific variables and macroeconomic variables influenced new cost efficiency of banking sectors in European Union countries during the period 2008-2017. They found that the statistically significant variables were: capitalisation, profitability, loan risk, market structure, conditions of the economy and inflation. According to the results of analysis by Gavurova et al. (2017a), the efficiencies in case of Northern and Western European banking sectors were higher than the average and the efficiencies in case of Southern and Eastern European banking sectors were under the total average in the whole sample.

Staehr and Uusküla (2020), based on a 20-year panel data analysis in EU countries, explored the relationship between macroeconomic indicators and macro-financial factors and the level of financial stability of the banking system through the volume of inefficient loans. Kim, Batten, and Ryu (2020) investigated this problem using OECD countries as an example. Dankiewicz and Simionescu (2020) point out that the level of financial stability of the country is also regulated by the insurance market, in particular trade credit insurance, limiting, among others, the level of payment gridlocks and protecting against their consequences, as noted by Dankiewicz (2016). Younsi and Nafla (2019), using the case of 40 developed and developing countries, studied the relationship among financial stability, monetary policy and economic growth based on panel data for the period 1993-2015 and concluded that trade openness, capital account openness and foreign direct investment were the most positive factors contributing to the improvement of financial stability. Tsagkanos, Evgenidis, and Vartholomatou (2018) investigated the relationship between financial and monetary stability using the case of the Euro zone and BRICS countries. The authors justified that the difference lies in different modes of financial turmoil, and, therefore, is accompanied by various impulse reactions.

Nasreen and Anwar (2020), using the aggregate financial stability index, estimated the relative impact of financial and economic integration on South Asian countries. The authors concluded that this process did not contribute to the financial stability of countries in the long run, reducing the level of financial security for each of them.

Lepers and Serrano (2020) suggested an interesting approach. They created a financial vulnerability index tailored to emerging economies, grouping 32 indicators around four poles: valuation and risk appetite, imbalances in the nonfinancial sector, financial sector vulnerabilities, and global vulnerabilities. This approach made it possible to define where the risk arises and how it extends to other parts of the financial system. Besides, the relationship between this index and the business cycle and the credit cycle was investigated.

According to the authors, the economic categories of financial stability and financial security are closely related, since in both cases the ability of the country's financial system to absorb external and internal shocks is evaluated. Research in this area is being actively pursued both in Poland and in Ukraine. 
Among studies on the financial security of a state, conducted in Ukraine, the work of Koilo (2018) deserves attention. The author analyzes the key characteristics of financial security and proposes an approach to assessing an integral indicator, based on a taxonomic approach with the division of indicators into groups of direct and indirect impact, incentives and disincentives. She also takes into account the assessment of six separate areas (indicators that characterize bank security, debt, budget, foreign exchange, monetary and nonbank market security). The study focuses on government debt security, given that Ukraine is actively attracting loans from international financial institutions (Koilo, 2018).

Later Koilo et al. (2020) have proposed a new methodology for assessing the government debt security based on four indicators such as solvency, liquidity and domestic and external debt for emerging economies. Mataibayeva et al., (2019) conducted similar studies for the Republic of Kazakhstan, given the importance of public debt for the development of the country's financial system and its financial security. Vitlinskyi and Makhanets (2019) also emphasize the importance of monitoring the interplay of financial stability and public finance security.

Chetverikova (2020) analyzesthe financial situation of the VisegrádFour countries, including Poland. She point to general economic results and considers them to be the main triggers for the economic development of these countries and the improvement of their financial health.

Kozera (2016) examined the relationship between local finance debt levels as part of public debt and the level of financial security of Poland. Based on an analysis of 2007-2013 data, the author concluded that debt in major cities negatively affected financial security and socio-economic development of the country.

Gudzovata (2019), focusing on the role of monetary policy in ensuring the financial security of Ukraine, states that the effectiveness of monetary policy is insufficient, which is manifested in the imbalance of monetary circulation, inflation volatility, a significant share of cash in circulation, reduction of cash circulation, decrease in lending activity of banks, etc.Using the principal component method and building a regression model, the author concludes that there is a statistically significant relationship between monetary policy and financial security of the country. Corporate governance exercise a direct influence on bank risk and such a link is directly visible in time of financial crisis, like the crisis of 2008 (Augusto Felicio et al., 2018).

Yelisyeyeva (2018) summarizes theoretical foundations ofUkraine's financial security, performs its statistical modeling according to the method proposed by The National Institute for International Securityproblems(Ukraine), anddefines the forecast of changes in the level of financial security for 20122016. It is determined that, first of all, it isnecessary to take measures to ensure the stable operation of the banking sector, which is the main financial intermediary for Ukraine, as well as to increase the level of monetarysecurity. The author also points to the need to improve investment attraction tools and reduce the negative trade balance. Study results of (Apostoaie and Bilan, 2019) confirm that shadow banking is prone to macroeconomic conditions and that economic growth positively affects the expansion of this financial sector segment.

Bukhtiarova et al. (2018), using regression analysis of factors affecting financial security, found the relationship between the condition of financial intermediaries and the monetary market status.Later, Bukhtiarova, Semenog, Razinkova, Nebaba, and Haber (2020), assessing the level of financial monitoring system efficiency in the banking system of Ukraine through the integral indicator, noted that the level of financial security of a country is largely determined by measures that help counteract legalizing proceeds from crime.Vyhovska, Polchanov, Aldiwani, and Shukairi (2019), and Khalatur, Pavlova, and Zhylenko (2018) studied the ability of the financial system of Ukraine and identified possible areas for strengthening its financial security.Financial security is a function of financial risk information avoidance. Higher level of financial literacy and financial risk information availability increase the level of financial security (BlajerGołębiewska et al., 2018). 
Zachosova, Herasymenko, and Shevchenko (2018) believe setting up financial security at the macro level is largely defined by the conditions created at the micro level and, accordingly, the level of financial inclusion of the population, as well as the access of economic entities to financial products and services. The authors systematized the possible positive effects, problems of financial inclusion and the corresponding risks to the state's financial security.

Ostrowska -Dankiewicz (2019) thinks that the new regulatory and supervisory paradigm of the financial market enforces consumer protection of innovative financial products, including insurance products, thus becomes an opportunity to increase the safety of buyers. As a result of independent and separate supervision appearance, an approach to the protection of consumer rights is also of special importance, strengthened by the application of pro-consumer solutions defined by supervising institutions regarding the reduction of information deficit in the applicable distribution.

Given the literature review, it should be noted that financial stability and financial security studies are conducted in different countries, with different development levels of both the economy and the financial system. The input data used are largely general, and the results obtained characterize the ability of a particular financial system to absorb both external and internal financial shocks and ensure a continuous flow of capital across all economic agents.

\section{DATA AND METHODOLOGY}

This study is based on data that describe the state of financial systems of Poland and Ukraine for the period 2007 to 2018. For the calculation, four groups of indicators were developed in terms of both countries, given the special aspects of the existing financial system in Ukraine and Poland, the availability of relevant data for the analyzed period, and their comparability for both countries. The National Bank of Ukraine, the National Bank of Poland, The Polish Financial Supervision Authority and the National Securities and Stock Market Commission (Ukraine) were the source of the data. All indicators were classified into four groups. The first group of indicators characterizes the development of financial intermediaries and includes the asset size of banks, insurance companies, assets of other financial institutions, and the number of ATMs per 100,000 adults as a financial inclusion indicator.The second group describes the situation on the monetary market and includes broad money to GDP, the rate of national currency against the US dollar, the ratio of total loans to deposits, and the amount of loans and deposits to banks by the private sector. The third group of indicators reflects the situation on the stock markets of both countries and includes securities trading, market capitalization of domestic listed companies, and stock price volatility. The fourth group describes the state of public finances: the amount of foreign and domestic debt of the country, the state budget deficit in $\%$ of GDP, the amount of foreign exchange reserves, as well as the government bond 10year yield for Poland. Given no similar statistics on Ukraine, the government bond indicator is taken.

Assessing the state of the banking system, Shkolnik, Bukhtiarova, and Semenog (2017) tested the approach used in the current work in terms of the formation of an integral indicator based on Harrington's desirability function. In contrast to this study, Harrington's desirability function was used to analyze the dynamics of bank patterns using a self-organizing Kohonen map.

The study sequence was as follows. First, a system of indicators was identified, represented by the four groups mentioned above, and an input matrix $\mathrm{X}$ was formulated:

$$
X=\left[\begin{array}{ccc}
X_{11} & \cdots & X_{1 m} \\
X_{n 1} & X_{n m}
\end{array}\right]
$$

where $m$ denotesindicators characterizing the country's financial security; 
$n$ is the number of observations, years.

Secondly, given that the indicators taken for analysis have a different measurement scale, for comparison, they were normalized using the relative normalization method, and the maximum values in each analyzed indicator are taken as reference vectors.

$$
\begin{gathered}
E\left(e_{q}\right) \stackrel{N o r m}{\longrightarrow} E^{N}\left(e_{q}\right), q=1, \ldots, Q, \\
e_{q}^{N}\left(s_{k}\right)=\frac{e_{q}\left(s_{k}\right)}{e_{q}^{\text {Ideal }}}, k=1, \ldots, m \\
e_{q}^{\text {ideal }}=\left(\max _{S_{i} e S} e_{1}\left(s_{i}\right) ; \ldots ;\left(\max _{S_{i} e S} e_{q}\left(s_{i}\right) ; \ldots\left(\max _{S_{i} e S} e_{Q}\left(s_{i}\right)\right)\right.\right. \\
e_{q}^{N}\left(s_{k}\right)=\frac{e_{q}\left(s_{k}\right)}{\max _{S_{i} e S} e_{1}\left(s_{i}\right)}, q=1, \ldots, Q ; k=1, \ldots, m
\end{gathered}
$$

Third, the existing baseline data were optimized using Harrington's Desirability Function, by specifying partial functions for each metric group. Such calculations are based on the transformation of the natural values of the individual indicators into a dimensionless desirability scale, which is essentially a logistic Scurve, which reflects the objective laws of systems development, and therefore is used to evaluate economic systems, including financial ones. The desirability scale has an interval from 0 , which is the worst value, to 1 , the best value, and the closer the desirability value is to 0 or 1 , the lower the sensitivity. In the range from 0.2 to 0.8 , the sensitivity is maximum, that is, with a slight change in parameters, a significant change in desirability can occur, and therefore the possibilities for improving the state of the system under study are high. The quantification is based on the desirability criteria given by the formula:

$$
d_{k}=\exp \left(-\exp \left(-\overline{x_{k}}\right)\right)
$$

where $k$ is the number of indicators used to define desirability;

$d_{k}$ is a partial function according to the Harrington scale; and

$\overline{x_{k}}$ is a dimensionless indicator.

Fourth, the weighting coefficients werestandardizedusing Fishburn's rule:

$$
W_{i}=\frac{2(N-n+1)}{N(N+1)}
$$

where $W$ is the weight factor of the $i$-th indicator;

$N$ is the total number of indicators; and

$n$ is the indicator's weight.

Fifth, a generalized indicator for the chosen system of indicators is defined as an integral indicator of the state's financial security, and a forecast is created based on a polynomial of degree 2 , which is advisable to use to predict the behavior of economic systems.

The adequacy of the resulting assessment of the desirable level of the state'sfinancial securityis defined based on the following ranges:

$[0,80-1,00]$ - very high;

$[0,63-0,80]$ - high;

$[0,37-0,63]$ - moderate;

$[0,20-0,37]$ - low;

$[0,00-0,20]$ - very low. 
A complex indicator, which determines the level of financial security, is calculated as follows:

$$
D=\sqrt[n]{\prod_{i=1}^{n} d_{i}}
$$

where $n$ is the number of parameters that were compared in the system.

Sixth, a correlation and regression analysis was conducted, and economic and non-economic factors were found that have the most significant impact on the level of financial security in Ukraine and Poland.For this purpose, the values of integral indicators characterizing the level of development of different economic parameters were analyzed. The source matrix for determining the pairwise correlation included the following indices:

Corruption perceptions index, which is usually defined by Transparency International's theGlobalCoalitionAgainstCorruption for 180 countries (as of 2018). This is a generalized indicator, which is calculated based on statistics and expert assessment.Simultaneously, the level of corruption in the public sector and the economy is defined and the level of corruption in climate change, education, judicial system, health, water sector, and construction is assessed. Also, politicalcorruptionandaccesstoinformation are evaluated.Countries range from 0 to 100 , and the closer the index is to zero, the higher the level of corruption in a country. All these components have a hidden effect on the level of the country's financial security, as they indirectly affect the formation of financial flows in both the public and private sectors.

Property rights indexis an indicator that measures how the political and legal environment in the country contributes to the creation of a strong ownership regime for both physical and intellectual property. This index is defined for 129 countries, including Poland and Ukraine.The level of protection of property rights is critical for organizing the financial security of the state, since this affects the development level of both the banking system of the country and the stock market.

Fiscal freedom index is a complex indicator that considers tax pressure on businesses, both through direct and indirect taxes, at the state and local levels, and directly affects the state's financial security, since excessive tax pressure can lead to propelling some of the financial flows into the shadow economy and exacerbate pressure on legal financial flows, including in the stock market and the monetary market.

Business freedom index reflects the regulatory effectiveness of businessby the state and evaluates parameters in the context of business start-up procedures (number of procedures, time (days), cost (\% of income per capita), minimum capital (\% of income per capita)), licensing procedures (number of procedures, time (days), cost (\% of income per capita); and closing-a-business procedures (time (years), cost ( $\%$ of estate) andrecovery rate (cents on the dollar).

Labor freedom index includes six quantitative indicators characterizing the state of the labor market in a country, namely: Ratio of minimum wage to the average value added per worker, Hindrance to hiring additional workers, Rigidity of hours, Difficulty of firing redundant employees, Legally mandated notice period, andMandatory severance pay.The development of the labor market indirectly affects the financial security of a state and is primarily manifested in the fact that the level of accumulation and consumption of financial resources and investment activity of the population depends on the size of wages received by the population. This is reflected in the size of the deposit base and the crediting of the population for various purposes, including for house-buying or for consumer purposes, as well as in the development of voluntary insurance, which largely determines the state of financial intermediaries in the country.

Trade freedom index characterizes the availability of tariff and non-tariff barriers in the country that stimulate export or import activity. Export and import operations largely determine the exchange rate of the national currency - in this study, the Ukrainian hryvnia and Polish zloty against world currencies. The calculation of this indicator is based on the trade-weighted average tariff rate and non-tariff barriers. 
Investment freedom index estimates the economy of a country in terms of certain restrictions to both domestic and foreign investments and includes an impressive list of indicators, which characterize the National treatment of foreign investment, Foreign investment code, Restrictions on land ownership, Sectoral investment restrictions, Foreign exchange controls and Capital controls. Accordingly, capital control and control over currency transactions are directly related to the formation of the country's financial security.

\section{RESULTS}

As a result of calculations made according to a certain methodology (interim results for relative indicator normalization and partial normalization of the indicators by the Harrington function are given in Appendices A and B) in the context of Ukraine and Poland, the following results were obtained. Intermediate integral calculations by indicator groups showed different dynamics. In particular, when analyzing the behavior of indicators for Poland (Figure 1), one can find the upward dynamics for indices characterizing financial institutions and the money market. The constructed polynomial trends for these two indicators with a probability of 98.8 and $97 \%$, respectively, indicate further improvements in these indicator groups. Indicators reflecting the stock market condition show a slight downward trend, but the probability of approximation is much lower than the previous ones $-67.3 \%$. Of all the indicator groups, the condition of public finances has a strong downward trend. With that, the values of mean square standard deviation of the calculated indicators showed low volatility for the respective groups (Stock Market, Public Finance and Money - 3\%; Financial Institutions - 5\%).

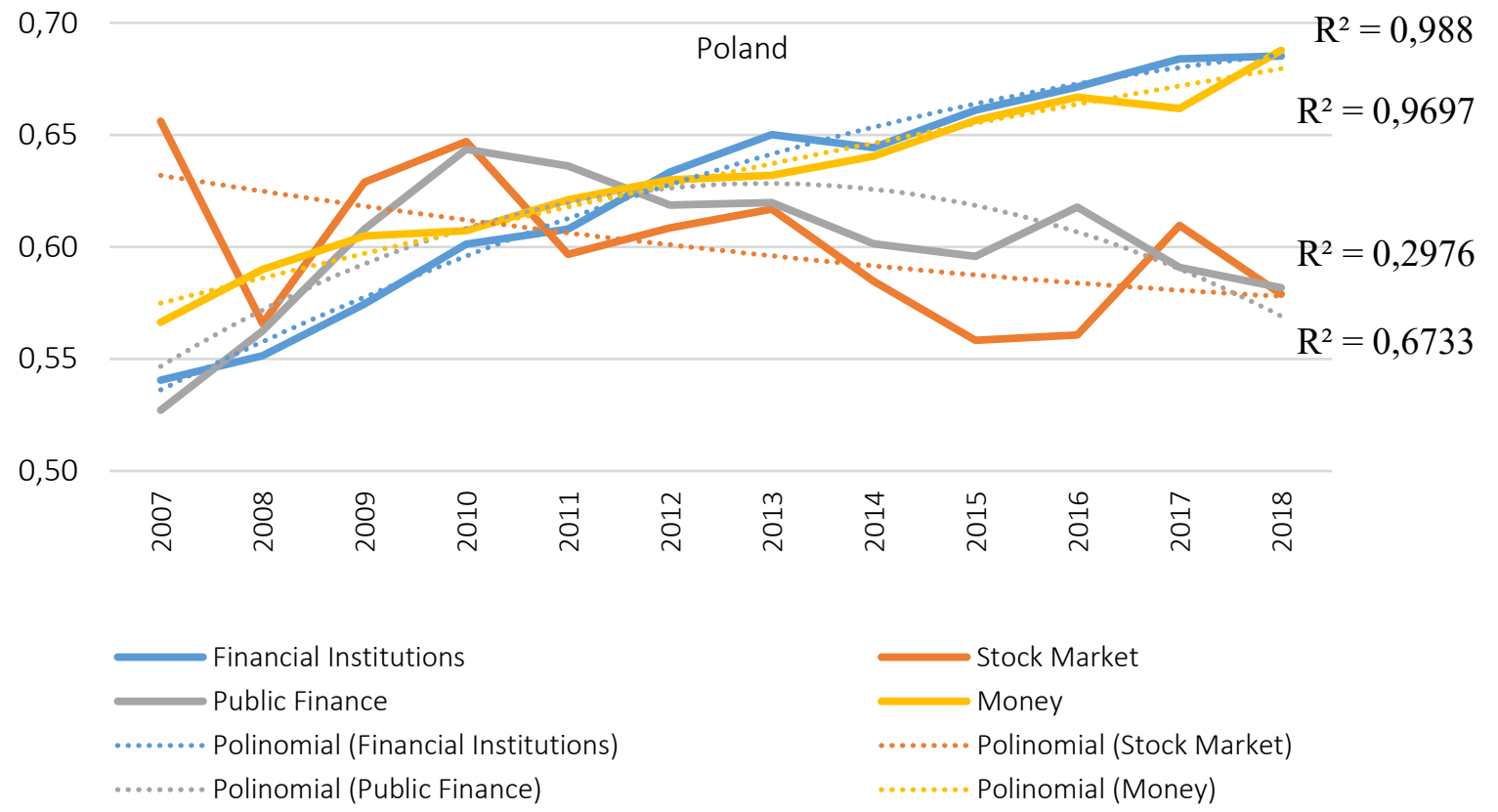

Figure 1. Change in values of integral indicators in the context of the analyzed groups, Poland Source: Author's calculations

When it comes to the behavior of integrated indicators by groups for Ukraine (Figure 2), it is worth noting that, compared to Poland, the volatility level is much higher, except for the condition of the monetary market, which has a similar indicator of 3\% for Financial Institutions; Stock Market accounts for 6\% and 
Public Finance is 5\%.It can be noted that the Financial Institutionsand Money indicators have dynamics similar to the Polish indicators and the high probability of positive dynamics approximation in the future. The behavior of the integral index characterizing the state of the stock market in Ukraine is fundamentally different. This is due to the strategic objectives put forward by Ukraine's financial regulators to clear the stock market from speculative securities. Accordingly, the adoption of many legislative and regulatory acts in 2016-2018 led to a significant decrease in the number of securities in circulation, the review of many companies whose securities were included in the first and second listing level and as a result, a significant decrease in the value of the market capitalization of domestic listed companies. In contrast to Poland, the dynamics of Ukraine's integrated public finance indicator has a moderate upward trend.

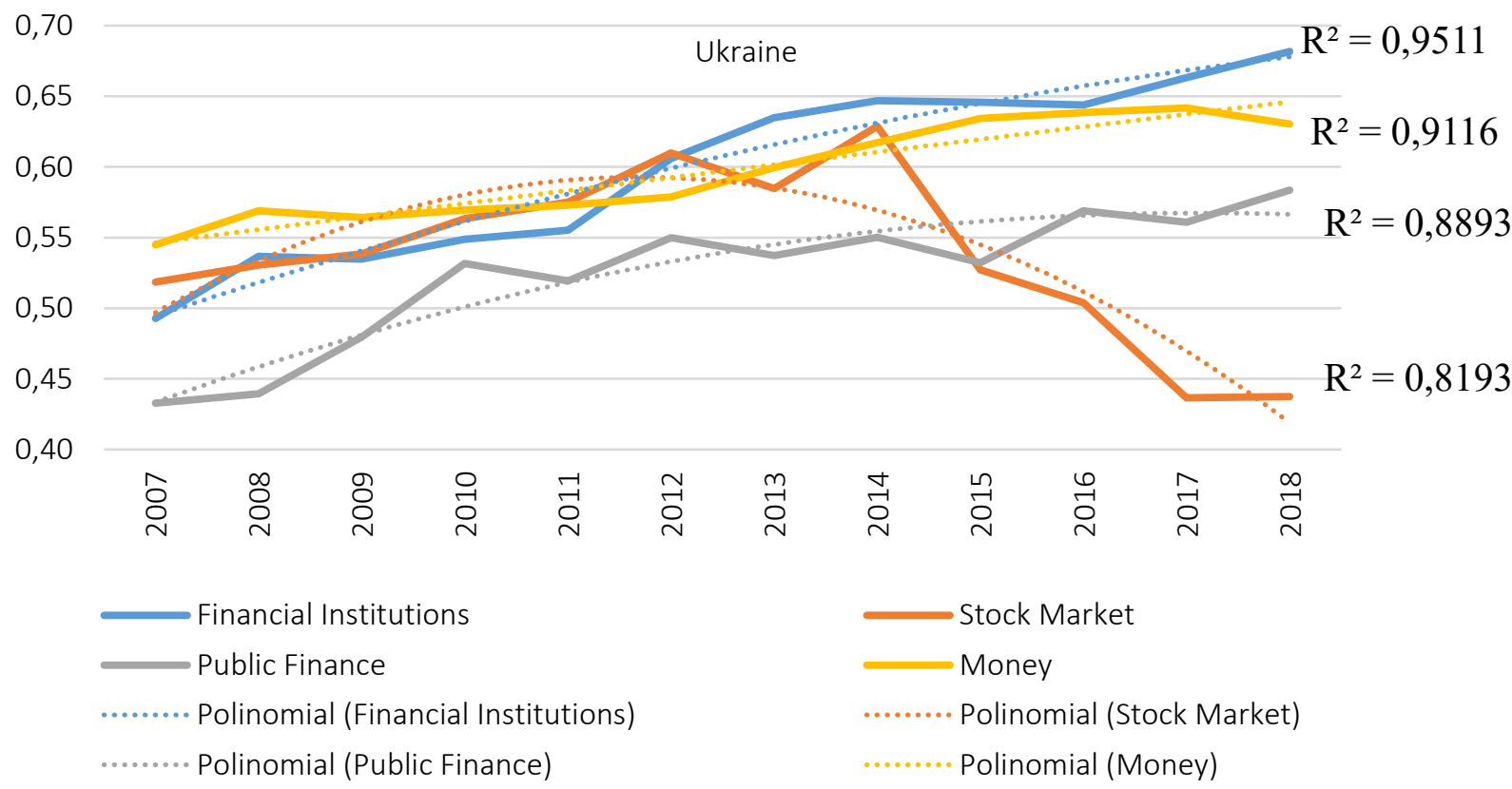

Figure 2. Change in values of integral indicators in the context of the analyzed groups, Ukraine Source: Author's calculations.

Analyzing the dynamic pattern of the calculated integral indicator (Figure 3), which reflects financial security, one can note that, first, the level of financial security of Poland is higher than Ukraine. However, if at the beginning of the analyzed period the gap between the indicators was 0.07 points, then it narrowed to 0.02 points at the end. Secondly, in both countries the value of the desirability function is within the interval of [0.37-0.63], which is characterized as satisfactory. Consequently, there is a high probability that, at low costs, the financial security of countries can be significantly improved and included in the interval that characterizes the value as high. It should also be emphasized that the intervals of the Harrington Desirability Scale attribute a value of 0.63 to a high level. That is, Poland demonstrates a high level of financial security, with the probability of approximation of the obtained results being high and accounting for $87.45 \%$ for Poland and $97.42 \%$ for Ukraine. 


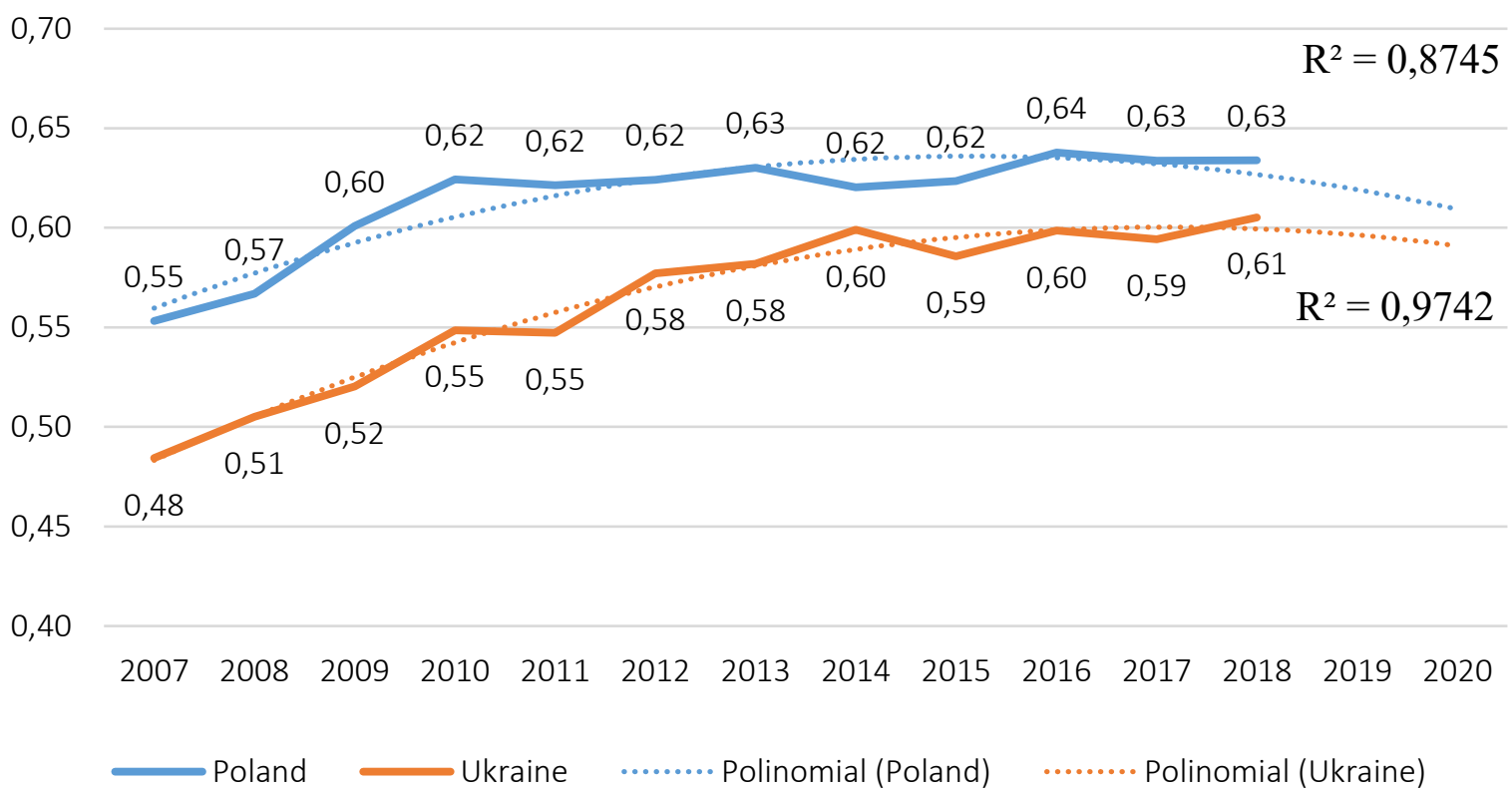

Figure 3. Change in the integral financial security indicator for Poland and Ukraine Source: Author's calculations.

Multiple linear regression model was used to determine the effect of the factors under study. As a result of calculating the Pearson correlation coefficient (Table 1)for all selected indicators, it was determined that there was a high level of dependence between financial security and most indices in Poland. Low strength of relationship is characteristic of Labor freedom index and Trade freedom index. However, none of the coefficients showed an inverse relationship. For further calculations, the above indicators will be excluded, and the other ones will be checked for multi collinearity.

Instead, the results of the Pearson coefficient calculations for Ukraine differ significantly by a weak connection for most of the indices studied; besides, the indices such as Freedom from corruption index, Fiscal freedom index, Labor freedom index and Investment freedom index are characterized by inverse weak dependence. Based on the results of these calculations for Ukraine and taking into account the construction of the regression model and determining the degree of factors' influence on the financial security of a company, it is advisable to choose Business freedom index and Trade freedom index. 
Table 1

Pearson correlation coefficient for selected indicators

\begin{tabular}{|l|c|c|c|c|c|c|c|}
\hline & $\begin{array}{c}\text { Freedom } \\
\text { from } \\
\text { corruption }\end{array}$ & $\begin{array}{c}\text { Property } \\
\text { rights }\end{array}$ & $\begin{array}{c}\text { Fiscal } \\
\text { freedom }\end{array}$ & $\begin{array}{c}\text { Business } \\
\text { freedom }\end{array}$ & $\begin{array}{c}\text { Labor } \\
\text { freedom }\end{array}$ & $\begin{array}{c}\text { Trade } \\
\text { freedom }\end{array}$ & $\begin{array}{c}\text { Investment } \\
\text { freedom }\end{array}$ \\
\hline Poland & 0.88383 & 0.87073 & 0.76123 & 0.79822 & 0.03223 & 0.59804 & 0.81474 \\
\hline Ukraine & -0.10604 & 0.158615 & -0.30987 & 0.783094 & -0.48428 & 0.657484 & -0.39869 \\
\hline
\end{tabular}

Source: Author's calculations.

After checking the indicators for Poland for multicollinearity among the Financial security, Freedom from corruption, Property rights, Fiscal freedom, Business freedom and Investment freedom indices, two indicators are identified that will be further used to build a multiple linear regression model - Freedom from corruption and Business freedom; other indicators had multicollinearity.
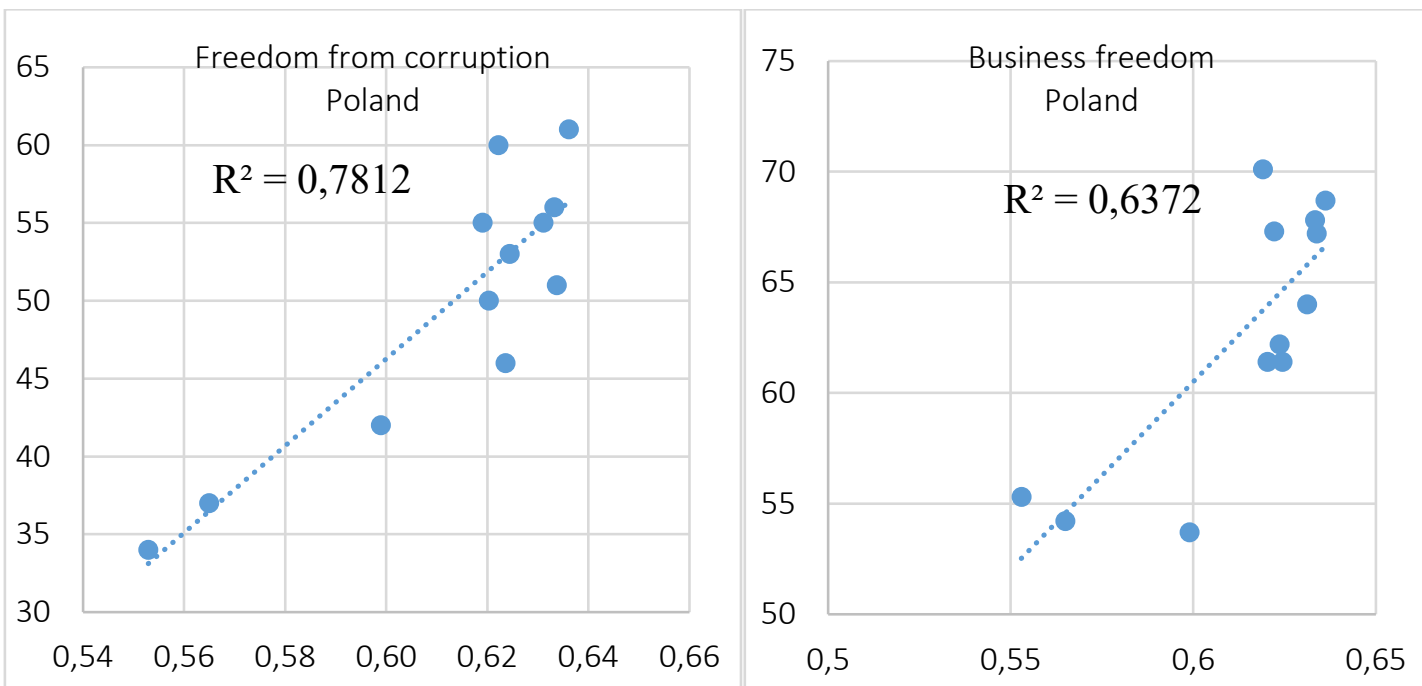

Figure 4. Correlation matrices for selected variables, Poland

Source: Author's calculations.

The constructed correlation matrices between Financial Security index and Freedom from corruption index, Financial Security index and Business freedom, as well as the formed linear trends show that in the first case the high value of $\mathrm{R}_{2}$ is obtained, i.e. the approximation probability is $78 \%$, in the second case the value is lower, but still quite high.

Baseline data and the intermediate calculations of the multiple linear regression model are shown in Appendix D. The calculations resulted in a regression equation for Poland, which is as follows:

$$
\mathrm{y}=0,463+0,003 * \mathrm{X}_{1}+0,0003 * \mathrm{X}_{2}
$$

An uncorrected multiple determination coefficient calculated in this model was $61.2 \%$, which made it possible to estimate the specific gravity of the result variation due to the factors considered in the overall 
result variation. In this case, the value of this coefficient indicates the average degree of factor correlation with the result.

Besides, elasticity coefficients for each factor indicated that a $1 \%$ increase in the financial security indicator could lead to a change in factors for 21.2 and 3.4\%. That is, the estimated factors have a low degree of elasticity, which may be due to a high level Harrington scale desirability of the integral value of the financial security indicator, and its further growth can be achieved at significant costs.

Overall, the results of calculations for Poland suggest that most of the factors studied were highly correlated with the financial security level being investigated. It is determined that the greatest financial security dependence is observed by the Freedom from corruption indicator.

Similar calculations have been made for Ukraine, but unlike Poland, among the selected factors, the highest degree of correlation is observed for Business freedom (0.82405) and Trade freedom (0.61809). On the other hand, unlike Poland, multi collinearity testing showed a small (only 40\%) correlation between the identified factors, and therefore they are more independent.

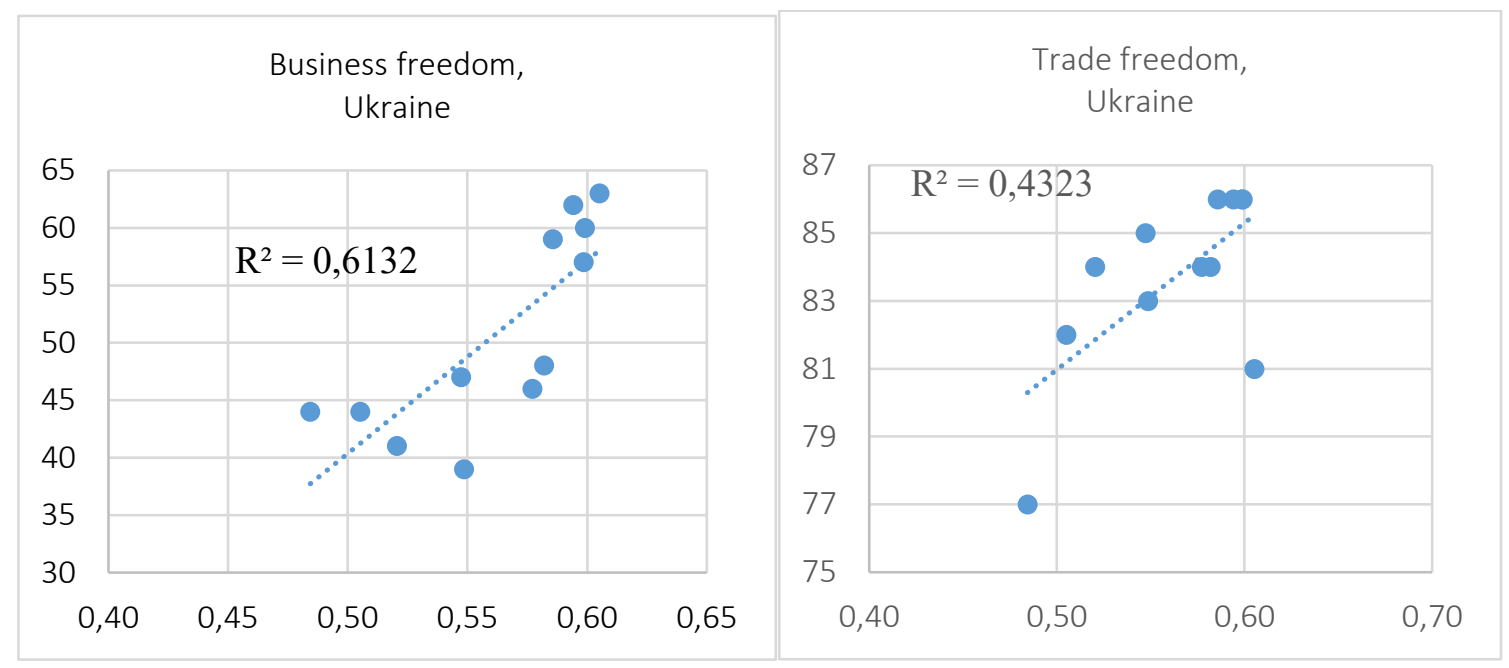

Figure 5. Correlation matrices for selected variables, Ukraine

Source: Author's calculations.

The correlation matrices for Ukraine show that, unlike Poland, linear trends are built, and the probability of $\mathrm{R}_{2}$ approximation for the selected factors of Business freedom and Trade freedom are significantly lower, amounting to $61 \%$ and $43 \%$, respectively.

Based on the calculations, whose initial data are given in Appendix $\mathrm{E}$, the regression equation for Ukraine is obtained. It should be noted that the coefficients $b_{1}$ and $b_{2}$, as well as the values of the free term are quite insignificant, which is consistent with the Pearson correlation coefficient.

$$
\mathrm{Y}=-0,107+0,003 * \mathrm{x}_{1}+0,006^{*} \mathrm{x}_{2} .
$$

An unadjusted multiple determination coefficient of $57 \%$ indicates the average level of communication and the average impact of Business freedom and Trade freedom factors on the financial security in Ukraine. The obtained elasticity coefficients for this model, in contrast to the results obtained for Poland, indicate that the financial security indicator responds much more strongly to the change in Business freedom $(3.4 \%$ for Poland and $26 \%$ for Ukraine), and has more than $90 \%$ elasticity for Trade freedom.

Thus, the financial security of Ukraine is determined by Business Freedom and Trade freedom. All other factors, unlike Poland, have a negligible effect, and half of them are inversely related. 


\section{CONCLUSION}

This research allows formulating the following conclusions:

Todate, the scientific literature proposes many approaches to studying the level of financial security of countries, but they differ in the list of indicators taken as baseline data. This is due to the nature of the financial architecture in the country and the level of its economic and financial development.

The study of financial security in Poland and Ukraine, on the basis of 2007 to 2018 data, showed that the groups of indicators characterizing development of financial institutions, the monetary market, the stock market and public finances show unstable dynamics and significant volatility. Despite this, the calculated integral indicators using the Harrington Desirability Function for each country showed a gradual improvement in financial security. In 2018, Poland demonstrated a high level of financial security, while Ukraine was in the middle range, and its financial security was assessed as satisfactory. Given the results, 0.63 for Poland and 0.61 for Ukraine, both countries have high potential for improving financial security and combating external and internal shocks.

The use of the multiple linear regression model revealed that, among the factors selected for the analysis - Freedom from corruption, Property rights, Fiscal freedom, Business freedom, Labor freedom, Trade freedom and Investment freedom - two factors with the highest influence on the country's financial security were identified: for Poland - Freedom from corruption and Business freedom, due to high correlation between all factors and the signs of multi collinearity; and for Ukraine - Business freedom and Trade freedom, due to low correlation among all factors.

Given the emergence of a new factor - the coronavirus pandemic - which has a significant negative impact on economic development at the global level, further studies will analyze its impact on the financial security status in the context of the countries studied.

\section{ACKNOWLEDGEMENT}

Comments from the Editor and anonymous referees have been gratefully acknowledged. Inna Shkolnyk gratefully acknowledges financial support from the Ministry of Education and Science of Ukraine (0118U003585).

\section{REFERENCES}

Apostoaie, C.M., Bilan, I. (2020). Macro determinants of shadow banking in Central and Eastern European countries, Economic Research-Ekonomska Istrą̌ivanja, 33(1), 1146-1171, https://doi.org/10.1080/1331677X.2019.1633943.

Augusto Felício, J., Rodrigues, R., Grove, H., Greiner, A. (2018). The influence of corporate governance on bank risk during a financial crisis, Economic Research-Ekonomska Istraživanja, 31(1), 1078-1090, https://doi.org/10.1080/1331677X.2018.1436457

Belas, J., Smrcka, L., Gavurova, B., \& Dvorsky, J. (2018). The Impact of Social and Economic Factors in the Credit Risk Management of SME. Technological and Economic Development of Economy, Volume 24 Issue 3: 1215-1230.

Belas, J., Kocisova, K., Gavurova, B. (2019). Determinants of Cost Efficiency: Evidence from Banking Sectors in EU Countries. Acta Polytechnica Hungarica, Vol. 16, No.5, pp: 101-123.

Blahun, I. S., \& Blahun, I. I. (2020). The relationship between world and local stock indices. Montenegrin Journal of Economics, 16(1), 41-53. DOI: 10.14254/1800-5845/2020.16-1.4

Blajer-Gołębiewska, A., Wach, D., Kos, M. (2018). Financial risk information avoidance, Economic Research - Ekonomska Istraživanja, 31(1), 521-536, https://doi.org/ 10.1080/1331677X.2018.1439396.

Bukhtiarova, A., Semenog, A., Razinkova, M., Nebaba N., \& Haber J. A. (2020). Assessment of financial monitoring efficiency in the banking system of Ukraine. Banks and Bank Systems, 15(1), 98-106. doi: $10.21511 /$ bbs.15(1).2020.10

Chetverikova, A. S. (2020). The Visegrad countries in the EU: Economic results. World Economy and International Relations, 64(2), 63-70. DOI: 10.20542/0131-2227-2020-64-2-63-70 
Cihak, M., Demirguc-Kunt, A., Feyen, E., \& Levine, R. (2012). Benchmarking financial systems around the world (Policy Research working paper, no. WPS 6175). Washington, DC: World Bank. Retrieved fromhttp://documents.worldbank.org/curated/en/868131468326381955/Benchmarking-financial-systemsaround-the-world

Dankiewicz R, Simionescu M. (2020), The Insurance Market in Romania: a Macroeconomic and a Microeconomic Approach, Transformations in Business \& Economics, Vol. 19, No1 (49), p. 250.

Dankiewicz, R. (2016), Insurance of Export Credits as a Tool Supporting International Trade. Annales Universitatis Mariae Curie-Sktodowska Lublin - Polonia, Sectio H Oeconomia, Vol. L, 4, pp. 49-58. DOI:10.17951/h.2016.50.4.49

Demirgüç-Kunt, A., Feyen, E., \& Levine, R. (2013). The Evolving Importance of Banks and Securities Markets. Oxford University Press on behalf of the World Bank. Retrieved from https://openknowledge.worldbank.org/handle/10986/21618 License: CC BY-NC-ND 3.0 IGO.

Gavurova, B., Belas, J., Kocisova, K., Dapkus, R., Bartkute, R. (2017a). Revenue and Cost Efficiency of Banking Sectors in The European Union Countries: Do They Depend on Size, Location or Crisis Period? Transformations in Business \& Economics, Vol. 16, No 2 (41), pp.124-146.

Gavurova, B., Packova, M., Misankova, M., \& Smrcka, L. (2017b). Predictive potential and risks of selected bankruptcy prediction models in the slovak business environment. Journal of Business Economics and Management, 18(6), 1156-1173.

Gudzovata, O. (2019). Mekhanizmy realizatsii hroshovo-kredytnoi polityky v systemi zmitsnennia finansovoi bezpeky Ukrainy [Mechanisms of monetary and credit policy realization in the system of strengthening financial security of Ukraine] (Doctoral dissertation). Kyiv: Kyiv National Institute for Strategic Researches. Retrieved from http://old2.niss.gov.ua/public/File/aspirantura/ Gudzovata Dyser_2.pdf

Haber, J. A., Bukhtiarova, A., Chorna, S. Iastremska,O., \& Bolgar, T. (2018). Forecasting the level of financial security of the country (on the example of Ukraine). Investment Management and Financial Innovations, 15(3), 304-317. doi:10.21511/imfi.15(3).2018.25

International Property Rights Index. Proprty Rights Alliance. (2019). Retrieved from https://www.internationalpropertyrightsindex.org

Khalatur, S., Pavlova, G., \& Zhylenko, K. (2018). The role of some indicators of financial security in Ukraine in the context of transnationalization and national interests. Investment Management and Financial Innovations, 15(3), 237 248. doi: $10.21511 /$ imfi.15(3).2018.20

Kim, H., Batten, J. A., \& Ryu, D. (2020). Financial crisis, bank diversification, and financial stability: OECD countries. International Review of Economics and Finance, 65, 94-104. doi:10.1016/j.iref.2019.08.009

Koilo, V., Ryabushka, L., Kubakh, T., \& Halik, J (2020). Assessment of government debt security of emerging markets: theory and practice. Investment Management and Financial Innovations, 17(1), 35-48. doi:10.21511/imfi.17(1).2020.04

Kozera, A. (2016). The debt of the metropolises in Poland in 2007-2013 [Zadłużenie metropolii w Polsce w latach 2007-2013]. Studia Regionalne i Lokalne, 65(3), 70-93. DOI: 10.7366/1509499536504

Lepers, E. \& Serrano, A. S.(2020). Decomposing financial (in)stability in emerging economies. Research in International Business and Finance, 51. DOI: 10.1016/j.ribaf.2019.101068

Ligazakon. (n.d.). Pro zatverdzhennia Metodychnykh rekomendatsii shchodo rozrakhunku rivnia ekonomichnoi bezpeky Ukrainy: Nakaz Ministerstva ekonomichnoho rozvytku i torbivli Ukrainy No. 1277 vid 29.10.2013 r. [On the approval of methodical recommendations on computation of the economic security level in Ukraine: the Order of the Ukrainian Ministry for Economic Development and Trade No. 1277 dated October 29, 2013]. Retrieved from http://search.ligazakon.ua/1_doc2.nsf/ link1/ME131588.htm

Mataibayeva, G., Makysh, S., Kuchukova, N., Zhalbinova, S., \& Zhussupova, A. (2019). Conceptual approaches to the public debt management and its impact on financial stability. Entrepreneurship and Sustainability Issues, 7(2), 14961513. doi:10.9770/jesi.2019.7.2(49)

Ministry for Development of Economy, Trade and Agriculture of Ukraine. (n.d.). Metodyka rozrakbunku rivnia ekonomichnoi beapeky Ukrainy. [The method for computation of the economic security level in Ukraine.]. Retrieved from http://www.me.gov.ua/control/uk/publish/article?art_id=97980\&cat_id=38738 
Nasreen, S., \& Anwar, S. (2020). Financial stability and the role of economic and financial integration in south asia: Evidence from time-series data. Singapore Economic Review, 65(2), 303-333. doi:10.1142/S0217590817500011

Ostrowska-Dankiewicz, A. (2019). Consumer protection policy in the Polish life insurance market in the aspect of current legal regulations. Investment Management and Financial Innovations, 16(4), 168-180. DOI:10.21511/imfi.16(4).2019.15

Ruinan, L. (2019). Comparison of Bank Efficiencies between the US and Canada: Evidence Based on SFA and DEA. Journal of Competitiveness, 11(2), 113-129. https://doi.org/10.7441/joc.2019.02.08

Shkolnyk, I., Kozmenko, S., Kozmenko, O., \& Mershchii, B. (2019). The impact of economy financialization on the level of economic development of the associate EU member states. Economics and Sociology, 12(4). 43-58. DOI: 10.14254/2071-789X.2019/12-4/2

Staehr, K., \& Uusküla, L. (2020). Macroeconomic and macro-financial factors as leading indicators of non-performing loans: Evidence from the EU countries. Journal of Economic Studies. doi:10.1108/JES-03-2019-0107

The National Bank of Ukraine. (n.d.). Financial Sector Statistics Data. Retrieved from https://bank.gov.ua/statistic/sector-financial/data-sector-financial\#1ms

The National Securities and Stock Market Commission. (2019). Analytical data on stock market development. Retrieved from http://www.nssmc.gov.ua/fund/analytics

Transparency International: the global coalition against corruption. (2019). Retrieved from https://www.transparency.org

Tsagkanos, A., Evgenidis, A., \& Vartholomatou, K. (2018). Financial and monetary stability across euro-zone and BRICS: An exogenous threshold VAR approach. Research in International Business and Finance, 44, $386-393$. doi:10.1016/j.ribaf.2017.07.108

Vitlinskyi, V., \& Makhanets, L. (2019). Modeling the stability of the country's financial system. 8th International Conference on Monitoring, Modeling and Management of Emergent Economy: Experimental Economics and Machine Learning for Prediction of Emergent Economy Dynamics, M3E2-EEMLPEED 2019. Ukraine, Odessa. Paper presented at the CEUR Workshop Proceedings, 2422, 335-344.

Valaskova, K., Kliestik, T., \& Kovacova, M. (2018). Management of financial risks in Slovak enterprises using regression analysis. Oeconomia Copernicana, 9(1),105-121.

Vyhovska, N., Polchanov, A., Aldiwani K., \& Shukairi, F. (2019). The methodological approaches development to assess the creation and use of the financial capacity of the state. Public and Municipal Finance, 8(1), 28-43. doi: $10.21511 / \mathrm{pmf} .08(1) .2019 .03$

Yelisyeyeva, O. K. (2018). Statystychne modeliuvannia finansovoi bezpeky Ukrainy [Statistical Modeling of the Financial Security in Ukraine]. Naukoryi Visnyk. Natsionalnoi Akademii Statystyky, Obliku ta Audytu,1-2 (56-57), 10-18. Retrieved from http://194.44.12.92:8080/ispui/handle/123456789/3209

Younsi, M., \& Nafla, A. (2019). Financial stability, monetary policy, and economic growth: Panel data evidence from developed and developing countries. Journal of the Knowledge Economy, 10(1), 238-260. doi:10.1007/s13132-0170453-5

Zachosova, N., Herasymenko, O., \& Shevchenko, A. (2018). Risks and possibilities of the effect of financial inclusion on managing the financial security at the macro level. Investment Management and Financial Innovations, 15(4), 304319. doi:10.21511/imfi.15(4).2018.25 


\section{APPENDIX A}

Normalized values of selected indicators using the relative normalization method

\begin{tabular}{|c|c|c|c|c|c|c|c|c|c|c|c|}
\hline 2007 & 2008 & 2009 & 2010 & 2011 & 2012 & 2013 & 2014 & 2015 & 2016 & 2017 & 2018 \\
\hline & \multicolumn{11}{|l|}{ Ukraine } \\
\hline 0,4408 & 0,6811 & 0,6474 & 0,6929 & 0,7754 & 0,8290 & 0,9400 & 0,9685 & 0,9225 & 0,9210 & 0,9828 & 1,0000 \\
\hline 0,4585 & 0,5968 & 0,5973 & 0,6438 & 0,6849 & 0,8002 & 0,9449 & 1,0000 & 0,8643 & 0,7981 & 0,8167 & 0,9037 \\
\hline 0,0494 & 0,0773 & 0,0670 & 0,1085 & 0,0573 & 0,3452 & 0,3999 & 0,5205 & 0,7007 & 0,7217 & 0,8288 & 1,0000 \\
\hline 1,0000 & 0,9610 & 0,7616 & 0,6934 & 0,6214 & 0,5938 & 0,6584 & 0,6376 & 0,5995 & 0,5686 & 0,5876 & 0,4556 \\
\hline 0,3852 & 0,6644 & 0,6251 & 0,6226 & 0,6771 & 0,6909 & 0,7765 & 0,8796 & 0,9018 & 0,9001 & 0,9331 & 1,0000 \\
\hline 0,3011 & 0,3904 & 0,3822 & 0,4804 & 0,5738 & 0,6533 & 0,7684 & 0,7851 & 0,8311 & 0,8822 & 0,9642 & 1,0000 \\
\hline 0,1857 & 0,1936 & 0,2864 & 0,2917 & 0,2929 & 0,2938 & 0,2939 & 0,4370 & 0,8031 & 0,9394 & 0,9778 & 1,0000 \\
\hline 0,1510 & 0,1924 & 0,2574 & 0,3705 & 0,3880 & 0,5976 & 0,6725 & 1,0000 & 0,1377 & 0,0424 & 0,0373 & 0,0172 \\
\hline 0,2980 & 0,3490 & 0,4217 & 0,6076 & 0,8578 & 1,0000 & 0,6626 & 0,9214 & 0,8585 & 0,8406 & 0,1852 & 0,2334 \\
\hline 1,0000 & 0,9899 & 0,8489 & 0,7195 & 0,5854 & 0,5705 & 0,5373 & 0,4683 & 0,4680 & 0,4050 & 0,3679 & 0,3488 \\
\hline 0,8736 & 0,8621 & 0,8522 & 0,8835 & 0,8416 & 0,8777 & 0,9888 & 1,0000 & 0,8280 & 0,7657 & 0,6710 & 0,5623 \\
\hline 0,0492 & 0,0791 & 0,1250 & 0,1672 & 0,1800 & 0,1921 & 0,2053 & 0,4469 & 0,7594 & 0,9013 & 0,9933 & 1,0000 \\
\hline 0,0236 & 0,0593 & 0,1209 & 0,1880 & 0,2143 & 0,2526 & 0,3411 & 0,6119 & 0,6743 & 0,8902 & 1,0000 & 0,9893 \\
\hline 0,0164 & 0,0189 & 0,0813 & 0,2910 & 0,7030 & 1,0000 & 0,5928 & 0,5654 & 0,2055 & 0,2789 & 0,2104 & 0,3339 \\
\hline 0,1347 & 0,2222 & 0,6549 & 1,0000 & 0,3013 & 0,6380 & 0,7492 & 0,8384 & 0,3838 & 0,4949 & 0,2694 & 0,2795 \\
\hline 0,9123 & 0,7666 & 0,7666 & 1,0000 & 0,9196 & 0,7099 & 0,5905 & 0,2179 & 0,3847 & 0,4494 & 0,5440 & 0,7318 \\
\hline \multirow[t]{2}{*}{0,5048} & 0,6776 & 0,7042 & 0,7372 & 0,8112 & 0,8926 & 1,0000 & 0,9134 & 0,8367 & 0,8525 & 0,9403 & 0,9373 \\
\hline & \multicolumn{11}{|l|}{ Poland } \\
\hline 0,2800 & 0,3687 & 0,4380 & 0,5689 & 0,6123 & 0,6852 & 0,7198 & 0,7534 & 0,8279 & 0,8591 & 0,9367 & 1,0000 \\
\hline 0,6570 & 0,7134 & 0,7193 & 0,7509 & 0,7565 & 0,8423 & 0,8668 & 0,9241 & 0,9325 & 0,9583 & 0,9814 & 1,0000 \\
\hline 0,5483 & 0,4339 & 0,5558 & 0,6898 & 0,6866 & 0,8387 & 1,0000 & 0,7477 & 0,8295 & 0,8714 & 0,9637 & 0,9168 \\
\hline 0,7660 & 0,8869 & 0,9117 & 0,8801 & 0,8870 & 0,8792 & 0,8546 & 0,8402 & 0,8302 & 0,8123 & 0,7953 & 1,0000 \\
\hline 0,4211 & 0,5293 & 0,5406 & 0,5784 & 0,6741 & 0,7180 & 0,7507 & 0,8223 & 0,8847 & 0,9571 & 0,9570 & 1,0000 \\
\hline 0,3225 & 0,4695 & 0,4928 & 0,5091 & 0,5979 & 0,6312 & 0,6415 & 0,6909 & 0,7344 & 0,7774 & 0,7611 & 1,0000 \\
\hline 0,7017 & 0,6110 & 0,7903 & 0,7648 & 0,7515 & 0,8260 & 0,8016 & 0,8002 & 0,9561 & 1,0000 & 0,9581 & 0,9164 \\
\hline 0,5621 & 0,5316 & 0,6805 & 0,7995 & 0,8367 & 0,9312 & 0,9081 & 0,8587 & 0,8115 & 0,9780 & 0,9685 & 1,0000 \\
\hline 1,0000 & 0,4291 & 0,7134 & 0,9012 & 0,6533 & 0,8383 & 0,9666 & 0,7981 & 0,6510 & 0,6554 & 0,9517 & 0,7584 \\
\hline 1,0000 & 0,5732 & 0,6280 & 0,7701 & 0,8103 & 0,6680 & 0,8053 & 0,6410 & 0,5837 & 0,5062 & 0,7542 & 0,6072 \\
\hline 0,6379 & 0,7051 & 1,0000 & 0,8278 & 0,5379 & 0,6074 & 0,4746 & 0,4572 & 0,4019 & 0,4881 & 0,4647 & 0,4676 \\
\hline 0,6914 & 0,7574 & 0,7674 & 0,7928 & 0,8227 & 0,8267 & 0,8638 & 0,9003 & 0,9390 & 0,9942 & 0,9737 & 1,0000 \\
\hline 0,3705 & 0,4601 & 0,5255 & 0,6104 & 0,7709 & 0,7881 & 0,7998 & 0,8715 & 0,9157 & 1,0000 & 0,8933 & 0,8837 \\
\hline 0,5860 & 0,6446 & 0,7175 & 0,7895 & 0,8094 & 0,8375 & 0,8926 & 0,7770 & 0,8289 & 0,9156 & 0,9626 & 1,0000 \\
\hline 0,8961 & 0,9921 & 1,0000 & 0,9447 & 0,9732 & 0,8170 & 0,6590 & 0,5745 & 0,4414 & 0,4961 & 0,5588 & 0,5226 \\
\hline 0,0238 & 0,2712 & 0,6271 & 1,0000 & 0,6102 & 0,3898 & 0,4915 & 0,3898 & 0,4068 & 0,4237 & 0,1186 & 0,0339 \\
\hline 0,4966 & 0,5951 & 0,6719 & 0,7022 & 0,7433 & 0,7765 & 0,8052 & 0,8757 & 0,9451 & 1,0000 & 0,9909 & 0,9767 \\
\hline
\end{tabular}




\section{APPENDIX B}

Partial indicator normalization (Harrington Desirability Function)

\begin{tabular}{|c|c|c|c|c|c|c|c|c|c|c|c|}
\hline 2007 & 2008 & 2009 & 2010 & 2011 & 2012 & 2013 & 2014 & 2015 & 2016 & 2017 & 2018 \\
\hline \multicolumn{12}{|l|}{ Ukraine } \\
\hline 0,5254 & 0,6029 & 0,5925 & 0,6064 & 0,6309 & 0,6463 & 0,6766 & 0,6841 & 0,6720 & 0,6716 & 0,6878 & 0,6922 \\
\hline 0,5314 & 0,5766 & 0,5768 & 0,5914 & 0,6040 & 0,6381 & 0,6779 & 0,6922 & 0,6562 & 0,6375 & 0,6428 & 0,6669 \\
\hline 0,3860 & 0,3963 & 0,3925 & 0,4077 & 0,3890 & 0,4926 & 0,5115 & 0,5520 & 0,6088 & 0,6151 & 0,6463 & 0,6922 \\
\hline 0,6922 & 0,6821 & 0,6269 & 0,6066 & 0,5844 & 0,5757 & 0,5959 & 0,5894 & 0,5775 & 0,5676 & 0,5737 & 0,5304 \\
\hline 0,5064 & 0,5978 & 0,5855 & 0,5848 & 0,6016 & 0,6058 & 0,6313 & 0,6604 & 0,6664 & 0,6660 & 0,6748 & 0,6922 \\
\hline 0,4771 & 0,5082 & 0,5054 & 0,5387 & 0,5693 & 0,5943 & 0,6289 & 0,6338 & 0,6469 & 0,6611 & 0,6830 & 0,6922 \\
\hline 0,4358 & 0,4387 & 0,4719 & 0,4738 & 0,4742 & 0,4745 & 0,4746 & 0,5242 & 0,6389 & 0,6765 & 0,6865 & 0,6922 \\
\hline 0,4232 & 0,4382 & 0,4616 & 0,5014 & 0,5074 & 0,5769 & 0,6002 & 0,6922 & 0,4184 & 0,3835 & 0,3816 & 0,3742 \\
\hline 0,4760 & 0,4939 & 0,5190 & 0,5800 & 0,6544 & 0,6922 & 0,5972 & 0,6717 & 0,6545 & 0,6496 & 0,4356 & 0,4530 \\
\hline 0,6922 & 0,6896 & 0,6519 & 0,6145 & 0,5730 & 0,5682 & 0,5575 & 0,5347 & 0,5346 & 0,5132 & 0,5005 & 0,4939 \\
\hline 0,6587 & 0,6556 & 0,6528 & 0,6614 & 0,6498 & 0,6599 & 0,6893 & 0,6922 & 0,6460 & 0,6281 & 0,5998 & 0,5656 \\
\hline 0,3860 & 0,3969 & 0,4137 & 0,4291 & 0,4338 & 0,4381 & 0,4429 & 0,5275 & 0,6263 & 0,6663 & 0,6905 & 0,6922 \\
\hline 0,3766 & 0,3897 & 0,4122 & 0,4367 & 0,4462 & 0,4599 & 0,4911 & 0,5814 & 0,6008 & 0,6633 & 0,6922 & 0,6895 \\
\hline 0,3739 & 0,3748 & 0,3978 & 0,4735 & 0,6095 & 0,6922 & 0,5753 & 0,5666 & 0,4430 & 0,4693 & 0,4448 & 0,4887 \\
\hline 0,4173 & 0,4490 & 0,5948 & 0,6922 & 0,4772 & 0,5896 & 0,6233 & 0,6489 & 0,5060 & 0,5436 & 0,4659 & 0,4695 \\
\hline 0,6692 & 0,6284 & 0,6284 & 0,6922 & 0,6712 & 0,6116 & 0,5746 & 0,4474 & 0,5063 & 0,5284 & 0,5597 & 0,6181 \\
\hline 0,5468 & 0,6018 & 0,6099 & 0,6197 & 0,6413 & 0,6639 & 0,6922 & 0,6695 & 0,6485 & 0,6529 & 0,6767 & 0,6759 \\
\hline \multicolumn{12}{|l|}{ Poland } \\
\hline 0,4696 & 0,5008 & 0,5245 & 0,5677 & 0,5815 & 0,6041 & 0,6146 & 0,6245 & 0,6460 & 0,6547 & 0,6758 & 0,6922 \\
\hline 0,5955 & 0,6126 & 0,6144 & 0,6238 & 0,6254 & 0,6501 & 0,6569 & 0,6724 & 0,6746 & 0,6814 & 0,6874 & 0,6922 \\
\hline 0,5611 & 0,5231 & 0,5635 & 0,6055 & 0,6046 & 0,6490 & 0,6922 & 0,6228 & 0,6465 & 0,6581 & 0,6828 & 0,6705 \\
\hline 0,6282 & 0,6624 & 0,6691 & 0,6605 & 0,6624 & 0,6603 & 0,6535 & 0,6495 & 0,6466 & 0,6416 & 0,6367 & 0,6922 \\
\hline 0,5187 & 0,5549 & 0,5586 & 0,5708 & 0,6007 & 0,6140 & 0,6237 & 0,6444 & 0,6618 & 0,6811 & 0,6811 & 0,6922 \\
\hline 0,4847 & 0,5351 & 0,5429 & 0,5482 & 0,5770 & 0,5875 & 0,5907 & 0,6058 & 0,6189 & 0,6315 & 0,6268 & 0,6922 \\
\hline 0,6091 & 0,5811 & 0,6353 & 0,6279 & 0,6240 & 0,6455 & 0,6385 & 0,6381 & 0,6809 & 0,6922 & 0,6814 & 0,6703 \\
\hline 0,5655 & 0,5556 & 0,6027 & 0,6379 & 0,6485 & 0,6743 & 0,6681 & 0,6546 & 0,6414 & 0,6866 & 0,6841 & 0,6922 \\
\hline 0,6922 & 0,5215 & 0,6126 & 0,6662 & 0,5943 & 0,6489 & 0,6836 & 0,6375 & 0,5936 & 0,5950 & 0,6797 & 0,6260 \\
\hline 0,6922 & 0,5691 & 0,5865 & 0,6294 & 0,6410 & 0,5988 & 0,6396 & 0,5905 & 0,5724 & 0,5473 & 0,6247 & 0,5799 \\
\hline 0,5896 & 0,6102 & 0,6922 & 0,6460 & 0,5577 & 0,5800 & 0,5368 & 0,5310 & 0,5122 & 0,5413 & 0,5335 & 0,5344 \\
\hline 0,6060 & 0,6257 & 0,6286 & 0,6360 & 0,6445 & 0,6457 & 0,6560 & 0,6660 & 0,6764 & 0,6907 & 0,6854 & 0,6922 \\
\hline 0,5014 & 0,5319 & 0,5536 & 0,5809 & 0,6296 & 0,6346 & 0,6380 & 0,6582 & 0,6702 & 0,6922 & 0,6641 & 0,6615 \\
\hline 0,5732 & 0,5916 & 0,6139 & 0,6350 & 0,6407 & 0,6487 & 0,6639 & 0,6314 & 0,6463 & 0,6701 & 0,6826 & 0,6922 \\
\hline 0,6649 & 0,6902 & 0,6922 & 0,6779 & 0,6853 & 0,6429 & 0,5961 & 0,5695 & 0,5257 & 0,5439 & 0,5645 & 0,5527 \\
\hline 0,3767 & 0,4665 & 0,5862 & 0,6922 & 0,5809 & 0,5081 & 0,5424 & 0,5081 & 0,5139 & 0,5196 & 0,4114 & 0,3803 \\
\hline 0,5441 & 0,5761 & 0,6000 & 0,6093 & 0,6216 & 0,6313 & 0,6395 & 0,6593 & 0,6780 & 0,6922 & 0,6899 & 0,6862 \\
\hline
\end{tabular}




\section{APPENDIX C}

Normalized values in the context of the formed groups of indicators

\begin{tabular}{|l|c|c|c|c|c|c|c|c|}
\hline \multirow{2}{*}{ Year } & \multicolumn{4}{|c|}{ Poland } & \multicolumn{4}{c|}{ Ukraine } \\
\cline { 2 - 9 } & $\begin{array}{c}\text { Financial } \\
\text { Institutions }\end{array}$ & $\begin{array}{c}\text { Stock } \\
\text { Market }\end{array}$ & $\begin{array}{c}\text { Public } \\
\text { Finance }\end{array}$ & $\begin{array}{c}\text { Mone } \\
\mathbf{y}\end{array}$ & $\begin{array}{c}\text { Financial } \\
\text { Institutions }\end{array}$ & $\begin{array}{c}\text { Stock } \\
\text { Market }\end{array}$ & $\begin{array}{c}\text { Public } \\
\text { Finance }\end{array}$ & $\begin{array}{c}\text { Mone } \\
\mathbf{y}\end{array}$ \\
\hline 2007 & 0,5405 & 0,6561 & 0,5271 & 0,5664 & 0,4927 & 0,5186 & 0,4328 & 0,5449 \\
\hline 2008 & 0,5514 & 0,5658 & 0,5625 & 0,5900 & 0,5366 & 0,5305 & 0,4393 & 0,5689 \\
\hline 2009 & 0,5745 & 0,6289 & 0,6080 & 0,6049 & 0,5348 & 0,5385 & 0,4795 & 0,5642 \\
\hline 2010 & 0,6012 & 0,6470 & 0,6436 & 0,6072 & 0,5487 & 0,5633 & 0,5317 & 0,5695 \\
\hline 2011 & 0,6080 & 0,5967 & 0,6361 & 0,6210 & 0,5553 & 0,5752 & 0,5193 & 0,5728 \\
\hline 2012 & 0,6333 & 0,6086 & 0,6187 & 0,6300 & 0,6060 & 0,6099 & 0,5499 & 0,5787 \\
\hline 2013 & 0,6502 & 0,6168 & 0,6199 & 0,6320 & 0,6348 & 0,5846 & 0,5374 & 0,5994 \\
\hline 2014 & 0,6444 & 0,5847 & 0,6015 & 0,6405 & 0,6468 & 0,6288 & 0,5503 & 0,6171 \\
\hline 2015 & 0,6611 & 0,5583 & 0,5957 & 0,6565 & 0,6459 & 0,5270 & 0,5322 & 0,6344 \\
\hline 2016 & 0,6714 & 0,5607 & 0,6178 & 0,6669 & 0,6440 & 0,5038 & 0,5688 & 0,6386 \\
\hline 2017 & 0,6840 & 0,6096 & 0,5909 & 0,6618 & 0,6631 & 0,4366 & 0,5607 & 0,6418 \\
\hline 2018 & 0,6852 & 0,5789 & 0,5817 & 0,6878 & 0,6817 & 0,4375 & 0,5836 & 0,6303 \\
\hline
\end{tabular}

\section{APPENDIX D}

Output data for correlation-regression model calculations (Poland)

\begin{tabular}{|c|c|c|c|c|c|c|c|c|c|}
\hline No. & $\begin{array}{c}\text { Financial } \\
\text { security, } \\
y\end{array}$ & $\begin{array}{c}\text { Freedom } \\
\text { from } \\
\text { corruption } \\
\text { x1 } \\
\end{array}$ & $\begin{array}{c}\text { Business } \\
\text { freedom, } \\
\quad \times 2\end{array}$ & $\mathrm{yx} 1$ & $\mathrm{yx} 2$ & $\mathrm{x} 1 \mathrm{x} 2$ & $\mathrm{x} 12$ & $\mathrm{x} 22$ & $\mathrm{y}^{2}$ \\
\hline 2007 & 0,55 & 34 & 55,3 & 18,79890 & 30,57585 & 1880,20 & 1156,00 & 3058,09 & 0,30571 \\
\hline 2008 & 0,56 & 37 & 54,2 & 20,90232 & 30,61908 & 2005,40 & 1369,00 & 2937,64 & 0,31914 \\
\hline 2009 & 0,60 & 42 & 53,7 & 25,15395 & 32,16112 & 2255,40 & 1764,00 & 2883,69 & 0,35869 \\
\hline 2010 & 0,62 & 46 & 62,2 & 28,68453 & 38,78648 & 2861,20 & 2116,00 & 3868,84 & 0,38885 \\
\hline 2011 & 0,62 & 50 & 61,4 & 31,01223 & 38,08302 & 3070,00 & 2500,00 & 3769,96 & 0,38470 \\
\hline 2012 & 0,62 & 53 & 61,4 & 33,09095 & 38,33555 & 3254,20 & 2809,00 & 3769,96 & 0,38982 \\
\hline 2013 & 0,63 & 55 & 64 & 34,70902 & 40,38868 & 3520,00 & 3025,00 & 4096,00 & 0,39825 \\
\hline 2014 & 0,62 & 55 & 70,1 & 34,04757 & 43,39518 & 3855,50 & 3025,00 & 4914,01 & 0,38322 \\
\hline 2015 & 0,62 & 60 & 67,3 & 37,32878 & 41,87045 & 4038,00 & 3600,00 & 4529,29 & 0,38707 \\
\hline 2016 & 0,64 & 61 & 68,7 & 38,80157 & 43,69947 & 4190,70 & 3721,00 & 4719,69 & 0,40461 \\
\hline 2017 & 0,63 & 56 & 67,8 & 35,46219 & 42,93458 & 3796,80 & 3136,00 & 4596,84 & 0,40101 \\
\hline 2018 & 0,63 & 51 & 67,2 & 32,32122 & 42,58797 & 3427,20 & 2601,00 & 4515,84 & 0,40164 \\
\hline Amount & 7,360 & 600 & 753,3 & 370,31323 & 463,4374 & 38154,60 & 30822,00 & 47659,85 & 4,52271 \\
\hline Mean & 0,613 & 50 & 62,775 & 30,85944 & 38,61978 & 3179,55 & 2568,50 & 3971,65 & 0,37689 \\
\hline$\sigma y$ & \multicolumn{2}{|l|}{0,03} & \multicolumn{2}{|l|}{ b1 } & 0,0026002 & \multicolumn{2}{|c|}{$\begin{array}{c}\text { Standardized } \\
\text { coefficients }\end{array}$} & \multicolumn{2}{|c|}{ Elasticity coefficients } \\
\hline$\sigma \times 1$ & 8,28 & $\mathrm{~b} 2$ & & 3307 & $\beta 1$ & 0,821593 & & & 0,211965 \\
\hline$\sigma \times 2$ & 5,56 & $\mathrm{a}$ & 0,46 & 58695 & $\beta 2$ & 0,070241 & & & 0,033846 \\
\hline
\end{tabular}




\section{APPENDIX E}

Output data for correlation-regression model calculations (Ukraine)

\begin{tabular}{|c|c|c|c|c|c|c|c|c|c|}
\hline No. & $\begin{array}{l}\text { Financial } \\
\text { security, y }\end{array}$ & $\begin{array}{c}\text { Business } \\
\text { freedom, } \\
\text { x1 }\end{array}$ & $\begin{array}{c}\text { Trade } \\
\text { freedom, } \\
\text { x2 }\end{array}$ & $\mathrm{yx} 1$ & $\mathrm{yx} 2$ & $\mathrm{x} 1 \mathrm{x} 2$ & $\mathrm{x} 12$ & $\mathrm{x} 22$ & $y^{2}$ \\
\hline 2007 & 0,48435 & 44 & 77 & 21,31150 & 37,29513 & 3388 & 1936 & 5929 & 0,23460 \\
\hline 2008 & 0,50514 & 44 & 82 & 22,22604 & 41,42125 & 3608 & 1936 & 6724 & 0,25516 \\
\hline 2009 & 0,52042 & 41 & 84 & 21,33709 & 43,71502 & 3444 & 1681 & 7056 & 0,27083 \\
\hline 2010 & 0,54856 & 39 & 83 & 21,39370 & 45,53018 & 3237 & 1521 & 6889 & 0,30091 \\
\hline 2011 & 0,54728 & 47 & 85 & 25,72198 & 46,51848 & 3995 & 2209 & 7225 & 0,29951 \\
\hline 2012 & 0,57714 & 46 & 84 & 26,54843 & 48,47975 & 3864 & 2116 & 7056 & 0,33309 \\
\hline 2013 & 0,58199 & 48 & 84 & 27,93549 & 48,88711 & 4032 & 2304 & 7056 & 0,33871 \\
\hline 2014 & 0,59897 & 60 & 86 & 35,93794 & 51,51105 & 5160 & 3600 & 7396 & 0,35876 \\
\hline 2015 & 0,58567 & 59 & 86 & 34,55456 & 50,36767 & 5074 & 3481 & 7396 & 0,34301 \\
\hline 2016 & 0,59854 & 57 & 86 & 34,11687 & 51,47457 & 4902 & 3249 & 7396 & 0,35825 \\
\hline 2017 & 0,59416 & 62 & 86 & 36,83807 & 51,09796 & 5332 & 3844 & 7396 & 0,35303 \\
\hline 2018 & 0,60518 & 63 & 81 & 38,12650 & 49,01979 & 5103 & 3969 & 6561 & 0,36625 \\
\hline Amount & 6,74739 & 610 & 1004 & 346,04818 & 565,318 & 51139 & 31846 & 84080 & 3,81212 \\
\hline Mean & 0,56228 & 50,833 & 83,667 & 28,83735 & 47,10983 & 4261,58 & 2653,83 & 7006,67 & 0,32 \\
\hline$\sigma y$ & \multicolumn{2}{|l|}{0,04} & \multicolumn{2}{|l|}{ b1 } &, 0028856 & \multicolumn{2}{|c|}{$\begin{array}{c}\text { Standardized } \\
\text { coefficients }\end{array}$} & \multicolumn{2}{|c|}{ Elasticity coefficients } \\
\hline$\sigma \times 1$ & 8,35 & $\mathrm{~b} 2$ & 0,0 & 2409 & $\beta 1$ & 0,61942 & & & 0,260871 \\
\hline$\sigma \times 2$ & 2,56 & $\mathrm{a}$ & $-0,1$ & 55573 & $\beta 2$ & 0,41055 & & & 0,928637 \\
\hline
\end{tabular}

